\title{
Pemberdayaan Masyarakat melalui Program Rumah Literasi Kreatif di Kabupaten Kutai Kartanegara
}

\author{
Rachmat Dana Pratama ${ }^{1}$, Abdul Raji ${ }^{2}$, Hidayah Utama Lubis ${ }^{3}$, Hempri Suyatna ${ }^{4}$
}

\begin{abstract}
Abstrak
Sampai hari ini, sebagian besar penduduk dari daerah tertinggal di Indonesia masih menghadapi persoalan kualitas pendidikan yang kurang memadai. Mengeksplorasi program kolaborasi edukasi antara Rulika Bunga Kertas dan perusahaan Pertamina Hulu Sanga Sanga, makalah ini berupaya mengembangkan pemahaman tentang bagaimana inisiatif pemberdayaan diimplementasikan dengan menempatkan masyarakat lokal sebagai subjek pembangunan. Terkait dengan hal ini, sembilan pemangku kepentingan di Desa Beringin Agung, Kabupaten Samboja di wawancarai dan ditemukan bahwa pemberdayaan lembaga lokal telah berkontribusi efektif terhadap peningkatan literasi dasar bagi penerima manfaat. Selain itu, pemberdayaan agensi lokal juga terbukti telah memberikan efek keberlanjutan, mengindikasikan keberhasilan program. Secara keseluruhan, Rulika Bunga Kertas telah memainkan peranannya sebagai solusi efektif bagi warga dari daerah transmigrasi. Makalah ini dengan demikian, memberikan wawasan penting dalam studi tentang relasi komunitas-sektor swasta dalam inisiatif pemberdayaan.
\end{abstract}

Kata Kunci: Rumah Literasi Kreatif; Rulika Bunga Kertas; Taman Baca Masyarakat

\begin{abstract}
It is widely acknowledged that a key proportion of residents from backward areas in Indonesia are remained to suffer from inadequate quality of education. Exploring the case of a fruitful collaboration of Rulika Bunga Kertas and Pertamina Hulu Sunga company, this paper aims at developing an understanding of how empowerment initiatives are implemented by situating local communities as development subjects for improving education in Beringin Agung Village, Samboja District. Based on interviews with 9-stakeholders, the findings demonstrate that empowering local agencies have provided them with the necessary capacity to help their residents in improving basic literacy skills. Furthermore, the empowered local agency has contributed to sustainability, indicating a successful empowerment strategy. Overall, Rulika Bunga Kertas has expanded and played as an effective solution for residents from transmigration areas. This paper, therefore, offers essential insight into discussing the community-private sector relationship against empowerment initiatives..
\end{abstract}

Keywords: Rumah Literasi Kreatif; Rulika Bunga Kertas; Community Reading Gardens

\section{Pendahuluan}

Tingkat literasi di Indonesia masih relatif terbelakang (Suragangga, 2017). Survei UNESCO pada tahun 2011 turut memperlihatkan budaya membaca masyarakat di Indonesia berada pada posisi terendah dibandingkan dengan negaranegara yang ada di ASEAN dengan nilai 0,001 (Sudiana, 2020), menunjukkan bahwa hanya ada satu dari seribu penduduk di Indonesia yang tertarik untuk membaca. Dari 61 negara yang disurvei, minat baca masyarakat Indonesia berada pada posisi terbawah kedua (Central Connecticut State University, 2016). Peringkat tersebut jauh berada di bawah posisi Singapura di peringkat 36 dan Malaysia yang berada di peringkat 53 .

Budaya literasi yang rendah perlu mendapat perhatian serius, banyak studi menunjukkan bahwa remaja usia sekolah di Indonesia hanya dapat menuntaskan 17 halaman buku dalam kurun waktu satu tahun (Wandasari, 2017). Hal tersebut tentu sangat memprihatinkan. Minat baca yang rendah berkaitan erat dengan rendahnya literasi. Literasi perlu ditumbuhkembangkan sepanjang hayat. Pada era globalisasi yang serba digital, literasi dapat

\footnotetext{
${ }^{1}$ PT Pertamina Hulu Sanga Sanga Lapangan Mutiara (email korespondensi: rachmat.dana.p@mail. ugm.ac.id)

${ }^{2}$ PT Pertamina Hulu Sanga Sanga Lapangan Mutiara (email: abdul.raji@phh.pertamina.com)

${ }^{3}$ PT Pertamina Hulu Sanga Sanga Lapangan Mutiara (email: hidayah.lubis@phss.pertamina.com)

${ }^{4}$ Departemen Pembangunan Sosial dan Kesejahteraan, Universitas Gadjah Mada (email: hempriugm@ gmail.com)
} 
menjadi media efektif dalam mengurangi keterpaparan seseorang terhadap beragam informasi hoaks. Seseorang yang literat akan terus berkembang dalam hal pengetahuan dan keterampilannya yang bermanfaat dalam kehidupan sehari-hari.

Perhatian pemerintah terkait pentingnya peningkatan tingkat literasi masyarakat telah diberikan melalui Undang-Undang Nomor 43 Pasal 3 Tahun 2007. Dalam undang-undang tersebut disebutkan bahwa upaya menjadikan masyarakat terliterasi dimulai dari perpustakaan yang dianggap dapat menjadi media peningkatan kapasitas masyarakat. Meskipun demikian, sebaran perpustakaan masih sangat memprihatinkan. Data di dalam Peraturan Perpustakaan Nasional Tahun 2020 Tentang Rencana Strategis Pengembangan Perpustakaan Nasional Tahun 2020-2024 menunjukan hampir 50\% perpustakaan tersebar di Pulau Jawa. Di Pulau Kalimantan, perpustakaan hanya tersebar kurang dari 7\% saja. Perpustakaan desa yang ada di Desa Beringin Agung juga masih belum dibangun oleh pemerintah.

Merefleksikan kasus di tingkat nasional, masyarakat di Desa Beringin Agung, Kecamatan Samboja masih belum menjadikan minat baca sebagai bagian dari keseharian mereka. Berdasarkan hasil wawancara yang telah dilakukan, diperoleh informasi bahwa rendahnya minat baca masyarakat sebelum adanya Program Rulika Bunga Kertas di tahun 2019 disebabkan oleh beberapa faktor, di antaranya yaitu posisi desa transmigrasi yang jauh dari fasilitas publik, ketidakmampuan ekonomi masyarakat untuk membeli buku, tidak adanya perpustakaan desa, adanya anggapan masyarakat bahwa literasi merupakan keharusan bagi para pelajar saja, dan kurangnya wadah kalangan akademisi dari masyarakat sekitar untuk menyadarkan pentingnya literasi di masyarakat.

Berawal dari permasalahan tersebut, Walrina Munangsir kemudian menginisiasi taman baca Bunga Kertas untuk masyarakat desa. Pada mulanya, kegiatan di Taman Baca Bunga Kertas masih terbatas pada peminjaman buku dengan tempat berukuran kecil $3 \times 3$ meter untuk berkegiatan. Selain menjadi inisiator Taman Baca Bunga Kertas, Walrina Munangsir memiliki jejaring yang kuat dengan para stakeholder. Berbagai kegiatan seperti kepenulisan cerpen, puisi, video, buku, hingga membuat pakaian telah digeluti dan tertulis rapi di blog pribadinya. Upaya melek literasi menjadi upaya kolektif baik dari sisi institusi pendidikan, institusi perpustakaan nasional, dan taman baca masyarakat (Pramudyo et al, 2018).

Pada mulanya Taman Baca Masyarakat (TBM) merupakan transformasi dari Taman Pustaka Rakyat sejak tahun 1990-an (Ati, 2015). Keberadaan Taman Baca Masyarakat diatur dalam Undang-Undang Nomor 20 Tahun 2003 mengenai sistem pendidikan nasional, bahwa sistem pendidikan informal di antaranya terdiri dari lembaga pelatihan, kursus, majelis taklim, dan kelompok belajar masyarakat. Taman Baca Masyarakat (TBM) merupakan alternatif kelompok baca masyarakat yang mempermudah masyarakat dalam mendapatkan pengetahuan dan keterampilan untuk mengembangkan kapasitasnya. Terdapat penelitian sebelumnya yang penting untuk diulas.

Penelitian Saepudin dkk (2017) contohnya mengeksplorasi Taman Baca Permata Hati di Desa Narawita, Kecamatan Cicalengka Kabupaten Bandung yang fokus pada pendidikan anak usia dini. Kegiatan yang telah dilaksanakan di dalamnya berupa sarana ruang belajar, peminjaman buku, dan pendampingan pembelajaran. Dalam program pendampingan pembelajaran khusus untuk para anak-anak balita, terutama pendampingan belajar membaca dan menulis menggunakan pendekatan pendampingan teknik membaca, menulis kata dan kalimat, melaksanakan lomba cerdas cermat, dan lain-lain. Manfaat lain yang dirasakan oleh orang tua anak usia dini adalah disediakannya pelayanan koleksi umum untuk meningkatkan literasi mereka. Selain itu, masyarakat datang ke taman bacaan untuk berkumpul, dan mengobrol sehingga dapat mempererat hubungan antar sesama pengunjung.

Penelitian lain yang dilakukan oleh Dwiyantoro (2019) pada Taman Bacaan Masyarakat Mata Aksara menunjukkan bahwa dalam menumbuhkan minat baca pada masyarakat menitikberatkan Taman Baca sebagai tempat belajar dan pelestarian budaya. Taman bacaan masyarakat sangat membantu dalam pemberdayaan gemar membaca khususnya anak-anak, serta memberikan dampak yang positif bagi masyarakat di lingkungan taman bacaan dalam memajukan sektor pertanian dan peternakan masyarakat sekitar. Selain itu, TBM dapat dijadikan sebagai tempat berkumpul 
Rachmat Dana Pratama, Abdul Raji, Hidayah Utama Lubis, Hempri Suyatna - Pemberdayaan Masyarakat melalui Program Rumah Literasi Kreatif di Kabupaten Kutai Kartanegara

dan silaturahmi antar masyarakat di sekitar lingkungan taman bacaan.

Baru-baru ini, Fadila (2020) juga meneliti Taman Baca Tanah Ombak di Kampung Purus III, Kota Padang, Sumatera Barat. Dalam temuannya, taman bacaan tersebut telah berhasil mengubah perilaku masyarakat di sekitar Pantai Purus yang sangat jauh dari bahan bacaan dan suka berbicara kotor. Banyak anakanak yang datang ke taman baca untuk belajar membaca, bercerita, menggambar, mengaji, sholat berjamaah, belajar alat musik atau hanya untuk sekedar bermain berkumpul bersama. Dalam memberikan pemahaman kepada masyarakat kaitan keberadaan Taman Baca Tanah Ombak menghadapi berbagai rintangan. Namun hasilnya berbuah manis, Taman Baca Tanah Ombak dapat memberikan pemahaman dan edukasi kepada anak bahwa memiliki perilaku yang baik, sopan dan santun adalah cerminan generasi masa depan. Kepedulian masyarakat, mahasiswa, dan pemerintah sangat berpengaruh dalam meningkatkan literasi baca bagi anak-anak Indonesia.

Berdasarkan latar belakang di atas, perlu upaya kolektif dalam pengembangan Taman Baca Bunga Kertas. Semakin banyak pihak yang bekerja sama diargumentasikan akan semakin besar dampak keberadaan Taman Baca Bunga Kertas bagi masyarakat sekitar. PT Pertamina Hulu Sanga Sanga kemudian menggandeng Taman Baca Bunga Kertas bekerja sama dengan Pemerintah Desa Beringin Agung, Yayasan Teman Kita, dan Yayasan Borneo New membentuk Kampung Literasi Kreatif. Selain mencakup masyarakat secara umum, kolaborasi ini turut mencakup 1 Sekolah Menengah Pertama, 2 Sekolah Dasar, 2 Taman Kanak-Kanak dan 1 Play Group di Desa Beringin Agung dengan jumlah siswa siswinya kurang lebih sebanyak 189 laki-laki dan 175 perempuan.

Bersama PT Pertamina Hulu Sanga Sanga, Taman Baca Bunga Kertas bertransformasi menjadi Rumah Literasi Kreatif Bunga Kertas (Rulika Bunga Kertas) yang selama dua tahun terakhir bersama-sama bersinergi memastikan keberlanjutan program dan kebermanfaatan enam pola literasi dasar bagi masyarakat. Kegiatan yang telah dilakukan di Rulika Bunga Kertas tidak hanya sekedar kegiatan baca tulis, melainkan juga didukung oleh kelompok pemuda dalam menarik minat baca masyarakat dan peningkatan ekonomi melalui kelompok ibu-ibu Mamuja di bawah divisi literasi finansial. Penelitian ini lebih lanjut akan mengeksplorasi bagaimana proses pemberdayaan masyarakat yang telah dilakukan melalui kegiatan-kegiatan yang telah dilaksanakan di Rulika Bunga Kertas.

\section{Kerangka Teori}

Pemberian bantuan CSR perusahaan erat kaitannya dengan peningkatan kapasitas dan keterlibatan masyarakat sebagai subjek pemberdayaan. Pemberdayaan memiliki kata dasar "daya" yang memiliki arti kekuatan (Sulistyarni, 2004). Berkaitan dengan hal tersebut, Winarni (1998) mengemukakan pemberdayaan meliputi tiga tahapan yaitu pengembangan (enabling), memperkuat daya atau potensi (empowering), dan kemandirian. Melalui ketiga tahapan pemberdayaan yang harus dilalui itulah peningkatan kapasitas dan kemandirian masyarakat nantinya dapat terwujud (Winarni, 1998).

Dalam pengembangan masyarakat, potensi sumber daya yang dimiliki, pemberian wewenang, transfer pengetahuan dan keterampilan menjadi modal dasar dalam peningkatan kapasitas masyarakat (Suparjan \& Suyatna, 2003). Pemberdayaan adalah proses perubahan yang bersifat multidimensi yang bertujuan untuk mewujudkan kondisi seimbang antara kebutuhan dan sumber daya yang dilakukan dengan cara mengantisipasi, menyelesaikan persoalan, dan memanfaatkan peluang serta sumber daya yang ada (Soetomo, 2011). Dengan demikian, pengembangan masyarakat berarti memaksimalkan potensi lokal dan memberikan kesempatan bagi masyarakat untuk menggunakan potensi yang ada untuk kesejahteraan mereka. Pengelolaan Rulika Bunga Kertas melalui pemberdayaan masyarakat memerlukan tahapan-tahapan yang panjang, mulai dari tahapan perencanaan, tahapan implementasi dan tahapan pemantauan dan evaluasi (Sunaryo, 2013).

Pemberdayaan melalui Rulika Bunga Kertas tentu tidak dapat dipisahkan dengan literasi. Literasi merupakan pemaknaan informasi melalui teks (Kern, 2000). Dalam literasi diperlukan kemampuan nalar kritis dalam memaknai kontekstual dalam penggunaannya. Diskursus mengenai literasi sangat beragam dan dinamis. Literasi dimaknai tidak sekedar berkaitan dengan baca tulis, tetapi lebih luas berkaitan dengan praktik sosial di masyarakat. 
Kompleksnya praktik sosial tersebut berimplikasi pada beragamnya pengertian literasi di masyarakat (Alwasilah, 2002).

Literasi telah berkembang ke dalam enam jenis literasi berupa literasi dini, literasi dasar, literasi perpustakaan, literasi media, literasi teknologi, literasi visual (Clay, 2001). Literasi dini menjadi yang paling dasar dalam tahapan berliterasi. Literasi dini mencakup kemampuan dalam memahami ucapan dan berkomunikasi dengan sekitarnya. Pengalaman anak pada usia dini di lingkungan keluarga menjadi titik awal literasi dasar. Literasi dini menjadi tonggak awal anak usia dini dalam pengenalan lingkungan baik melalui gambar dan verbal yang ada di sekitarnya.

Literasi dasar merupakan lanjutan dari literasi dini. Literasi dasar berkaitan dengan kemampuan analitis anak dalam membaca, menulis, berhitung, memahami ucapan, dan menyampaikan secara verbal suatu informasi. Literasi perpustakaan berkaitan dengan kemampuan seseorang dalam membedakan jenis bahan bacaan, memahami klasifikasi pengetahuan, dan mampu menggunakan sumber informasi yang ada untuk menyelesaikan riset, pekerjaan, maupun suatu persoalan. Perpustakaan semestinya menjadi pusat belajar dan transformasi pengetahuan masyarakat. Pada era industri 4.0, kemampuan literasi media dan literasi teknologi sangat penting untuk mengetahui penggunaan berbagai media cetak dan media digital. Melalui literasi media, transfer pengetahuan secara global dengan cepat Literasi visual merupakan tahapan tertinggi seseorang dikatakan literat. Literasi visual berkaitan dengan kemampuan dalam memahami dan memaksimalkan analitis visual dan audiovisual media secara bertanggung jawab. Mudahnya arus penyebaran di berbagai media cetak dan online yang tidak terarah dapat memberikan pengaruh yang negatif bagi masyarakat.

Secara keseluruhan, terliterasi tidak cukup hanya baca tulis. Rulika Bunga Kertas memberikan kontribusi yang nyata dalam menumbuh-kembangkan budaya literasi sepanjang hayat bagi masyarakat melalui pengembangan enam literasi sebagaimana yang telah disampaikan sebelumnya. Tahapantahapan pemberdayaan masyarakat oleh Sunaryo (2013) akan menjadi kerangka berpikir dalam menggambarkan proses pengembangan Rulika Bunga Kertas dan teori literasi oleh Clay
(2001) akan digunakan untuk menggambarkan implementasi enam literasi dasar yang telah dilakukan.

\section{Metode Penelitian}

Penelitian mengenai pemberdayaan masyarakat yang telah dilakukan di Rulika Bunga Kertas menggunakan metode penelitian kualitatif deskriptif. Penelitian kualitatif menekankan interaksi mendalam antara peneliti dan informan untuk memahami suatu fenomena secara ilmiah (Herdiansyah, 2010). Metode ini bertujuan untuk mengetahui, memahami, dan menganalisis secara mendalam mengenai pelaksanaan 6 jenis literasi Rulika Bunga Kertas dalam memberdayakan masyarakat.

Teknik pengambilan data yang dilakukan yakni dengan melalui pengamatan, wawancara mendalam kepada pihak-pihak yang terlibat dengan Rulika Bunga Kertas, studi literatur, dan dokumentasi. Informan yang diwawancarai adalah Kepala Desa Beringin Agung, 2 orang relawan, dan 6 orang pengurus Rulika Bunga Kertas. Studi literatur dilakukan dengan menelaah dokumen-dokumen laporan pertanggung jawaban program mengingat Rulika Bunga Kertas merupakan program unggulan dari PT Pertamina Hulu Sanga Sanga. Penelitian dilakukan secara offline dengan penerapan protokol kesehatan pada bulan April 2021 di Desa Beringin Agung, Kecamatan Samboja sebagai wilayah Ring I PT Pertamina Hulu Sanga Sanga.

\section{Hasil}

Rulika Bunga Kertas menjadi sarana sumber belajar non-formal bagi peningkatan kualitas pendidikan masyarakat telah memunculkan peluang ekonomi baru, dan penyelesaian permasalahan sehari hari kehidupan masyarakat. Pengetahuan masyarakat akan terus bertambah seiring semakin bertambahnya koleksi-koleksi yang ada dan menerapkan ilmu yang diperoleh untuk mengembangkan kreativitas. Hal di atas sesuai dengan lima tujuan didirikannya Taman Baca Masyarakat bahwa kehadirannya berfungsi untuk menumbuhkembangkan kemampuan verbal dan non verbal, budaya membaca, menjadi sarana pembelajaran sepanjang masa, dan mewujudkan masyarakat yang memiliki pengetahuan dan keterampilan menuju kemandirian secara bertanggung jawab (Kementerian Pendidikan 
Rachmat Dana Pratama, Abdul Raji, Hidayah Utama Lubis, Hempri Suyatna - Pemberdayaan Masyarakat melalui Program Rumah Literasi Kreatif di Kabupaten Kutai Kartanegara

dan Kebudayaan, 2017). Keberadaan Taman Baca Masyarakat dengan berbagai jenis literasi yang dikembangkan memberikan alternatif untuk mengakses informasi baru berkaitan dengan peningkatan pengetahuan dan keterampilan yang diperlukan maupun sebagai sarana rekreasi keluarga yang menyenangkan bagi masyarakat di sekitarnya (Holik, 2013).

\section{Tahapan Perencanaan}

Proses pemberdayaan masyarakat dalam tahap perencanaan dilihat melalui keterlibatan masyarakat lokal dalam melihat peluang, pengembangan, antisipasi dampak negatif terhadap pelestarian lingkungan, dan alternatifalternatif pengembangannya (Sunaryo, 2013). Walrina Munangsir bersama orang-orang terdekat membentuk komunitas TBM Bunga Kertas dan mengidentifikasi potensi dengan membentuk diversifikasi literasi taman baca. Perencanaan pengembangannya turut dilaksanakan melalui Musrenbang pada setiap awal tahun untuk mencapai kesepakatan bersama. Diversifikasi tersebut memunculkan enam jenis literasi yang sebagian tidak hanya ditujukan untuk mengembangkan softskill melainkan juga peningkatan ekonomi masyarakat kaitannya dengan pemberdayaan. Selain bersinergi dengan pemerintah desa, TBM Bunga Kertas turut digandeng oleh PT Pertamina Hulu Sanga Sanga dalam menyediakan fasilitas pendukungnya. Di dalam proses pemberdayaan, masyarakat tidak hanya menjadi objek pembangunan, namun berperan penting dengan berpartisipasi sebagai subjek pengembangan TBM Bunga Kertas tersebut.

\section{"Saya dan teman-teman berinisiatifmendirikan Taman Baca Bunga Kertas untuk menjadi tempat berkumpul dan belajar. Desa Beringin Agung dulunya wilayah transmigrasi akses kita jauh ke fasilitas buku yang memadai." (Walrina, Wawancara 15 April 2021).}

Ketersediaan tempat belajar yang nyaman dan memadai menjadi hal penting untuk menunjang aktivitas belajar di TBM Bunga Kertas. Tempat yang terbatas memberikan kesan ketidaknyamanan bagi pembaca (Gong \& Irkham, 2012). Selain tempat yang luas, Taman Baca Masyarakat akan lebih menarik jika berada di lokasi yang strategis dan dilengkapi sarana prasarana yang lengkap. Berkaitan dengan hal tersebut, perluasan ruang baca Rulika Bunga Kertas menjadi langkah awal PT Pertamina Hulu Sanga Sanga untuk mendorong upaya masyarakat untuk meningkatkan kualitas literasi masyarakat.

Sarana prasarana di Rulika Bunga Kertas menjadi kebutuhan pokok untuk menunjang kegiatan masyarakat dalam berliterasi. Sarana prasarana yang memadai dianggap dapat meningkatkan kualitas literasi masyarakat menjadi semakin baik dan berkarakter. Rulika Bunga Kertas dapat menjadi pusat peningkatan pengetahuan, keterampilan, rekreasi pembelajaran, dan sumber belajar sepanjang hayat bagi masyarakat. Peningkatan sarana prasarana dapat membangkitkan minat baca masyarakat dan meningkatkan ragam literasi yang mereka kembangkan (Gong \& Irkham, 2012). Bantuan sarana prasarana pendukung sejak masuknya PT Pertamina Hulu Sanga Sanga pada awal tahun 2019 yang telah berikan di antaranya yakni berupa alat tulis kantor, alat mewarnai untuk anak-anak, buku, komputer, dan proyektor.

Pada tahun 2019, koleksi masih terbatas yakni hanya tersedia sekitar 50 buku saja milik Walrina Munangsir. Buku yang tersedia di Rulika Bunga Kertas Koleksi buku juga terus bertambah karena adanya bantuan donasi buku dari pihak lain seperti donasi dari Kementerian Pendidikan dan Kebudayaan, anggota DPRD Provinsi Kutai Kartanegara, keluarga alumni SMPN 15 Balikpapan, bakti sosial, dan masyarakat yang peduli pendidikan. Kini buku yang tersedia sudah mencapai lebih dari 1000 koleksi. Bantuan buku sangat diperlukan untuk mendukung kegiatan literasi karena lokasi Desa Beringin Agung yang cukup jauh dari perkotaan.

Pembagian aktivitas di Rulika Bunga Kertas tersegmentasi pada anak-anak, remaja, dan ibu-ibu. Rulika Bunga Kertas sebagai sumber peningkatan pengetahuan dan keterampilan masyarakat ditunjang oleh beragamnya koleksi buku, ketersediaan berbagai alat peraga pembelajaran, dan pelayanan TBM yang diberikan kepada masyarakat. Koleksi anak-anak banyak berupa komik dan sarana bermain untuk merangsang kegemaran membaca minimal 15 menit per harinya. Koleksi untuk remaja berupa buku Bahasa Inggris, alat seni tari, dan koleksi literasi teknologi. Koleksi yang disediakan untuk ibu-ibu rata-rata berupa buku-buku masak maupun berwirausaha. 
Inti dari proses pemberdayaan masyarakat melalui TBM Bunga Kertas pada tahap perencanaan adalah partisipasi masyarakat sebagai subyek pembangunan di dalamnya. Proses pemberdayaan dimulai dengan membentuk komunitas TBM Bunga Kertas, menggali potensi lokal dengan mengikuti Musrenbang, dan menjalin kemitraan lintas stakeholder untuk mengembangkan TBM Bunga Kertas. Pada tahap perencanaan, sinergitas TBM Bunga Kertas dengan Pemerintah Desa dan PT Pertamina Hulu Sanga Sanga sangat terlihat. Berkaitan dengan potensi lokal, pemberdayaan masyarakat erat kaitannya dengan upaya mensinergikan potensi lokal dengan kebutuhan masyarakat untuk meningkatkan kesejahteraan mereka (Soetomo, 2009).

\section{Tahapan Implementasi}

Sebelum adanya CSR PT Pertamina Hulu Sanga Sanga yang dimulai pada tahun 2019, fokus TBM Bunga Kertas masih terbatas pada kegiatan literasi baca tulis. Saat ini, implementasi Rulika Bunga Kertas berfokus pada penguatan 6 literasi pada berbagai bidang sekaligus menggali potensi-potensi yang ada sebagai keunikan desa. Literasi yang dikembangkan di Rulika Bunga Kertas terdiri dari literasi baca tulis, literasi literasi budaya dan kewarganegaraan, literasi numerasi, literasi sains, literasi digital, dan literasi finansial. Dengan peningkatan pengetahuan dan keterampilan, masyarakat diharapkan dapat mengaktualisasikan peluang ekonomi baru demi terciptanya keberlanjutan program dan kesejahteraan masyarakat itu sendiri.

\section{Literasi Baca Tulis}

Baca tulis merupakan dasar menuju tahapan-tahapan lanjutan dari literasi. Literasi baca tulis merupakan dasar dalam memahami dan menginterpretasikan makna tulisan untuk diaplikasikan di masyarakat. Upaya literasi baca tulis yang telah diimplementasikan di Rulika Bunga Kertas yakni kegiatan membaca dan bercerita, tebak kata, dan kelompok baca berkala.

Program Rulika Bunga Kertas bertujuan untuk meningkatkan minat baca berbagai tingkatan umur dan jenjang pendidikan di masyarakat. Masyarakat Desa Beringin Agung diperkenankan meminjam buku untuk dibawa pulang. Maksimal batas peminjaman buku yang diperbolehkan adalah selama 2 minggu. Menariknya, program tersebut memberikan fleksibilitas dalam masa pengembalian, yang berarti tidak ada denda diberikan apabila peminjam terlambat mengembalikan. Untuk memperluas jangkauan pembaca, relawan Rulika Bunga Kertas juga sering mengadakan taman baca keliling.

Rulika Bunga Kertas telah mampu mendorong minat baca anak-anak semakin besar. Untuk meningkatkan semangat, disediakan hadiah yang sumbernya dari para donatur dalam kegiatan baca tulis., Dari buku-buku yang disediakan anak-anak dapat memperkaya wawasan untuk belajar Bahasa Inggris yang selalu diasah dalam serial diskusi My English Club bersama Yayasan Teman Kita. Metode dalam mendorong minat baca anak-anak dilakukan dengan pertanyaan yang memantik keingintahuan dan pemberian reward kepada

Tabel 1

Kegiatan Rulika Bunga Kertas Sebelum dan Sesudah Adanya Pendampingan CSR PT Pertamina Hulu Sanga Sanga

\begin{tabular}{|c|c|c|}
\hline \multirow{2}{*}{ Jenis Literasi } & \multicolumn{2}{|r|}{ Program CSR PT Pertamina Hulu Sanga Sanga } \\
\hline & Sebelum & Sesudah \\
\hline Baca Tulis & $\begin{array}{l}\text { Baca tulis, diskusi, } \\
\text { layanan peminjaman }\end{array}$ & Kelompok baca berkala, diskusi, layanan peminjaman \\
\hline $\begin{array}{l}\text { Budaya dan } \\
\text { Kewarganegaraan }\end{array}$ & - & $\begin{array}{l}\text { Penulisan sejarah desa, seni tari, seni teater, seni rupa, kerajinan } \\
\text { dari barang-barang bekas, pelatihan kaligrafi }\end{array}$ \\
\hline Numerasi & - & Kelompok berhitung \\
\hline Sains & - & $\begin{array}{l}\text { Pengenalan lingkungan, belajar alat peraga sains, pembibitan ikan } \\
\text { air tawar, penanaman aquaponik, PHBS, diskusi }\end{array}$ \\
\hline Digital & - & Pemanfaatan perangkat komputer, pemanfaatan media sosial \\
\hline Finansial & - & $\begin{array}{l}\text { Pengembangan olahan nipah, olahan nanas, olahan pepaya, } \\
\text { kemampuan menjahit }\end{array}$ \\
\hline
\end{tabular}

Sumber: Olah Peneliti, 2021 
Rachmat Dana Pratama, Abdul Raji, Hidayah Utama Lubis, Hempri Suyatna - Pemberdayaan Masyarakat melalui Program Rumah Literasi Kreatif di Kabupaten Kutai Kartanegara

mereka. Semakin berkembangnya Rulika Literasi Kreatif memudahkan anak-anak dalam proses pembelajaran.

PT Pertamina Hulu Sanga Sanga bersama Yayasan Teman Kita turut membentuk kaderisasi calon pemimpin bangsa di Desa Beringin Agung melalui kegiatan Youth Camp yang telah dilaksanakan pada bulan April 2021. Pelaksanaan kegiatannya dilaksanakan di Pantai Coconut Beach, Kecamatan Samboja untuk membentuk karakter pemuda sekitar yang melek literasi. Peningkatan kapasitas pemuda juga disiapkan untuk diarahkan pada keikutsertaan mereka membesarkan Rulika Bunga Kertas. Keberhasilan seseorang dalam berliterasi turut ditentukan oleh dukungan lingkungan di sekitarnya.

\section{Literasi Budaya dan Kewarganegaraan}

Penulisan sejarah, potensi, dan budaya lokal Desa Beringin Agung merupakan upaya bersama seluruh lapisan masyarakat untuk memajukan dan melestarikan nilai-nilai lokal agar terus eksis di masyarakat. Penulisan tersebut dapat dipublikasikan di berbagai media cetak dan media online. Literasi budaya merupakan upaya untuk menggali pengetahuan tentang sejarah, kontribusi dan perspektif ragam kebudayaan. Kaitan dengan literasi kewarganegaraan merupakan pemahaman tentang kegiatan pemerintahan dan partisipasi masyarakat di dalamnya. Literasi budaya dan kewarganegaraan bertujuan untuk mendidik masyarakat tentang sejarah, perspektif budaya dan partisipasi masyarakat dalam pemerintahan. Literasi budaya dan kewarganegaraan diperlukan untuk mengembangkan kreativitas masyarakat dalam pengembangan dan pelestarian seni tradisional.

Terdapat beberapa kegiatan untuk mengasah bakat budaya anak-anak di Desa Beringin Agung. Kegiatan yang sudah dilakukan diantaranya berupa pembuatan kerajinan dari barang bekas seperti pemanfaatan kardus yang tidak terpakai menjadi topeng tradisional yang menarik dan memiliki nilai jual, menggambar, membuat baju dan peralatan kuda lumping, berlatih seni tari, mewarnai, pembuatan 99 kubus Asmaul Husna dari kertas bekas, dan pelatihan membuat kaligrafi. Karya seni budaya anak-anak bahkan pernah dipamerkan dalam Pameran Seni by Fokus yang menampilkan 20 Karya Topeng Art Installation.

Melalui ide-ide kreatif pemuda pemudi Desa Beringin Agung, Penari Tradisional (Borneo
Traditional Dance) pada pertengahan 2019 dari Rulika Bunga Kertas akhirnya terbentuk. Pembentukan ini tidak terlepas dari peran besar Walrina Munangsir dan Hendra Suprapto yang memfokuskan divisi literasi budaya dan kewarganegaraan menjadi salah satu fokus utama pengembangan awal Rulika Bunga Kertas. Hendra Suprapto kemudian berperan sebagai Dewan Pembina, Roy Irwansyah sebagai Ketua Divisi, Esti Wahyuni sebagai Wakil/Sekretaris, Evi Trisnawati sebagai Bendahara, Feri A. Taufik sebagai penanggung jawab seksi Musik, Gugun sebagai penanggung jawab seksi Teater, Tedy Irawan dan Fitri sebagai penanggung jawab seksi seni tari, dan Aisyah sebagai penanggung jawab seksi seni rupa.

"Di sini ada dua paguyuban seni Mas, kita selalu kolaborasi termasuk ketika ada kunjungan dari Kemendes di 2019 bersama sama menampilkan tarian sambutan.", (Walrina, Wawancara 15 April 2021).

Dua paguyuban Seni Kuda Lumping telah berdiri di Desa Beringin Agung jauh sebelum berdirinya Rulika Bunga Kertas. Salah satunya adalah Turonggo Lestari Budoyo. Paguyuban Seni yang menampilkan beraneka tari-tarian dari Pulau Jawa. Mulai dari Tari Sintren, Warok Ponorogo, Tari Sontoloyo, Jaran Kepang Temanggung, Tari Merak, Tari Cendrawasih dan Tari Rangda (Leak) kemudian berjalan beriringan dengan divisi literasi budaya dan kewarganegaraan Rulika Bunga Kertas. Melalui kolaborasi ini, regenerasi kesenian kepada anakanak semakin intens dilakukan. Ketika Rulika Bunga Kertas sedang mendapat kunjungan dari Direktorat Jenderal PKP2Trans, Kementerian Desa, Pembangunan Daerah Tertinggal, dan Transmigrasi pada 2019 secara sukarela kesenian Turonggo Lestari Budoyo tampil dalam menyambut kunjungan ke Desa Beringin Agung. Kolaborasi ini terus berlanjut untuk mewujudkan generasi muda yang terus menjaga dan mewariskan kebudayaan lokal kepada generasi mendatang. Pendekatan pemberdayaan menjunjung tinggi keberadaan kearifan lokal. Kearifan lokal merupakan budaya turun temurun yang telah teruji mampu menyeimbangkan kehidupan sosial dengan kelestarian alamnya (Soetomo, 2013).

Rulika Bunga Kertas terus berkembang menjadi pusat pengembangan kebudayaan 
masyarakat. Selain dijadikan sebagai tempat untuk live musik setiap malam, latihan seni tari, latihan seni rupa, dan latihan teater, Rulika Bunga Kertas juga dijadikan sebagai tempat persiapan kegiatan masyarakat seperti latihan Paduan Suara untuk Acara 17 Agustus maupun latihan bagi Kelompok Rebana Nurul Jadid yang merupakan salah satu kelompok Rebana yang aktif di desa Beringin Agung. Dari kolaborasi bersama Rulika Bunga Kertas pula, SMPN 5 Samboja berhasil menyabet juara 2 dalam ajang lomba videografi Schoolnet tahun 2019 dalam film pendek Aji Batara Agung Mencari Cinta yang dapat diakses melalui kanal Youtube Walrina Munangsir, Rin Muna.

\section{Literasi Numerasi}

Literasi berhitung yang dilakukan di Rulika Bunga Kertas dilaksanakan setiap satu minggu sekali untuk meningkatkan kemampuan masyarakat dalam memanfaatkan matematika dalam beragam kehidupan masyarakat. Analogi dan penalaran berhitung diajarkan dengan menggunakan konsep matematika dasar yang mudah dipahami. Kegiatan yang dilakukan berupa permainan hitung-hitungan yang waktu pelaksanaannya dibagi berdasarkan jenjang pendidikan masyarakat.

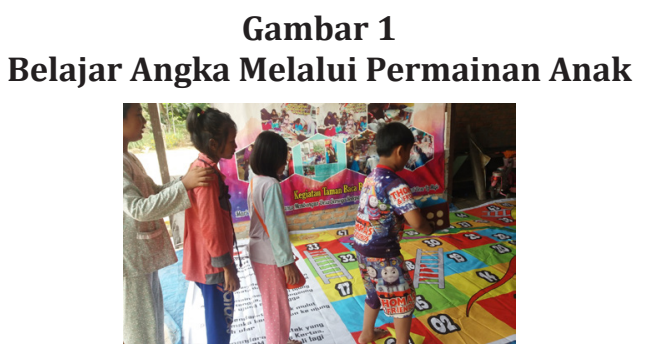

Sumber: Laporan Implementasi Rulika Bunga Kertas, 2020

\section{Literasi Sains}

Literasi sains yang telah dilakukan di Rulika Bunga Kertas berupa pengenalan lingkungan dan alam sekitar, belajar menggunakan alat pembelajaran, pembibitan ikan air tawar, penanaman sayuran aquaponik, dan penerapan hidup bersih sehat khususnya pada masa pandemi. Literasi sains yang telah dilakukan berkaitan dengan edukasi tentang cara mengidentifikasi kegunaan sains di kehidupan sehari-hari. Dengan mengetahui alur kegunaan sains, anak-anak hingga remaja di Desa Beringin Agung akan lebih semangat untuk terus mempelajari ilmu sains di sekitarnya. Selain itu, terdapat pendidikan terkait dengan cara memanfaatkan literasi sains untuk kegiatan ekonomi masyarakat.

Penggunaan akuaponikyang telah diterapkan merupakan perpaduan pemeliharaan ikan dan budidaya tanaman secara lebih efektif dan efisien. Tanaman yang dibudidayakan menjadi filter kotoran ikan secara alamiah. Air yang bersih dapat menjadikan ikan tidak mengalami stres dan lahap makan sehingga mempercepat pertumbuhan ikan.

\section{Gambar 2}

Pemutaran Film Dokumenter The Sexy Killers

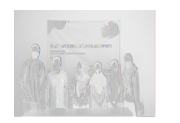

Sumber: Laporan Implementasi Rulika Bunga Kertas, 2020

Pada akhir tahun 2020, salah satu kegiatan diskusi menarik dilakukan bersama mahasiswa dan aktivis lokal pada pemutaran film dokumenter The Sexy Killers, masyarakat turut diajak berpikir kritis sebagai bagian dari upaya melek literasi sains. Film tersebut berkisah tentang energi listrik yang dihasilkan dari batu bara dan dampaknya pada orang di sekitarnya. Film dokumenter dari Watchdoc tersebut sebagian sentra ceritanya terjadi di wilayah Kalimantan Timur. Lebih lanjut, Desa Beringin Agung juga menjadi salah satu Desa yang menjadi wilayah operasi penambangan batu bara.

\section{Literasi Digital}

Literasi digital di era industri 4.0 yang serba cepatmerupakan kemampuanyang harus dimiliki melalui pemikiran terbuka, multidimensi, dan daya nalar yang tinggi dalam menerjemahkan informasi. Dalam literasi digital, pemanfaatan pengetahuan dan keterampilan yang diperoleh harus dilakukan secara bertanggung jawab. Kegiatan yang telah dilakukan di Rulika Bunga Kertas yakni berupa pemanfaatan komputer untuk berliterasi, belajar menggunakan media sosial untuk mempublikasikan kegiatan yang telah dilakukan, serta pemanfaatan media digital 
Rachmat Dana Pratama, Abdul Raji, Hidayah Utama Lubis, Hempri Suyatna - Pemberdayaan Masyarakat melalui Program Rumah Literasi Kreatif di Kabupaten Kutai Kartanegara

untuk berwirausaha. Rulika Bunga Kertas telah memiliki website dan media sosial yang secara aktif melakukan update konten digital.

Posisi Desa Beringin Agung yang strategis di dekat wilayah calon Ibukota Negara sangat memerlukan pengetahuan, keterampilan, dan kreativitas masyarakat yang mumpuni untuk menyongsong Ibukota Negara yang akan rampung tidak lama lagi. Dengan jumlah komputer yang terbatas, masyarakat sangat antusias untuk bisa mengoperasikan alat tersebut. Untuk memacu semangat masyarakat, pre test dan post test diberikan ketika masyarakat sedang belajar komputer. Poin yang paling banyak selama 1 bulan akan mendapatkan hadiah. Hadiah tersebut tentu berasal dari para donatur. Pada waktu tertentu, kemampuan Walrina Munangsir dalam menjalin hubungan baik dengan para stakeholder memberikan keuntungan dalam penyelenggaraan pelatihan fotografi dan videografi secara gratis kepada masyarakat.

\section{Literasi Finansial}

Menurut Otoritas Jasa Keuangan (2017), literasi finansial merupakan proses pembelajaran pengetahuan dan keterampilan masyarakat untuk mengelola kebutuhan anggaran dengan baik. Bentuk kegiatan literasi keuangan di Desa Beringin Agung yang telah dikembangkan adalah pengembangan UMKM olahan nipah, olahan nanas, olahan pepaya dan kemampuan menjahit. PT Pertamina Hulu Sanga Sanga turut menggandeng Borneo New dalam mendampingi kegiatan literasi finansial agar kegiatan di dalamnya terus terarah. Program ini diperuntukkan bagi orang dewasa, khususnya ibu-ibu yang terkumpul dalam komunitas Mamah Muda Samboja yang merupakan komunitas turunan dari Divisi Literasi Finansial.
Rulika Bunga Kertas mendorong peningkatan literasi finansial melalui ketersediaan sarana prasarana literasi yang lengkap seperti ketersediaan printer, komputer, buku wirausaha, mesin jahit, dan alat-alat kesenian. Peralatan kesenian seperti kostum adat Dayak dapat dipinjamkan untuk kegiatan literasi kebudayaan kewarganegaraan atau dijual untuk pemasukan tambahan khususnya bagi kelompok Mamuja.

Hasil buatan Kelompok Mamuja turut dipromosikan kepada pengunjung Rulika Bunga Kertas. Produksi UMKM Mamuja yakni berupa kreasi kreativitas dari daur ulang, pakaian, hingga kreativitas olahan makanan. Pada awal pandemi 2020, Rulika Bunga Kertas dengan cepat mengambil peluang pasar dengan produksi masker kain. Literasi finansial juga masih erat kaitannya dengan literasi budaya dan kewarganegaraan. Tarian adat Kalimantan di bawah Rulika Bunga Kertas juga sudah mulai dikenal masyarakat luas. Kelompok tari di bawah Rulika Bunga Kertas sudah sering mengikuti berbagai event pentas seni di wilayah Kutai Kartanegara. Tidak hanya itu, beberapa kegiatan pada literasi finansial juga ada yang dihibahkan sepenuhnya untuk bantuan sosial seperti pembuatan Education Card yang hasil penjualannya akan didonasikan untuk korban bencana alam di Kalimantan Selatan dan Sulawesi Barat tahun 2021. Pada hakikatnya pengembangan 6 literasi Rulika Bunga Kertas tidak terlepas dari kearifan lokal, baik berupa norma maupun budaya yang menjadi nilai-nilai luhur berkembangnya Taman Baca Masyarakat sehingga Rulika Bunga Kertas dapat mengoptimalkan potensi lokal yang dimiliki (Sunaryo, 2013).

\section{Tahapan Monitoring dan Evaluasi}

Monitoring dilakukan secara berkala oleh PT Pertamina Hulu Sanga Sanga secara periodik.

\section{Gambar 3
Pelatihan UMKM Mamuja}

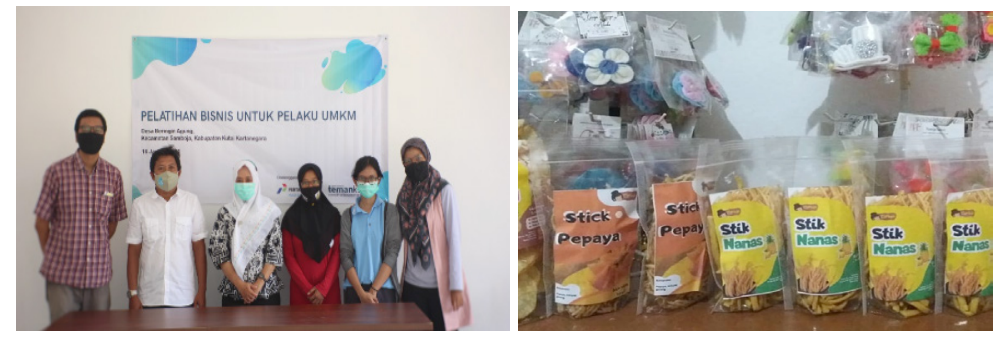

Sumber: Laporan Implementasi Rulika Bunga Kertas, 2020 
Selain itu, ketika ada kegiatan-kegiatan tertentu di Rulika Bunga Kertas perwakilan perusahaan turut menghadiri dan melakukan monitoring kegiatan. Pengawasan kegiatan juga dilakukan oleh Pemerintah Desa sebagai mitra kerja. Dengan kegiatan monitoring dan evaluasi yang rutin dilaksanakan, pengembangan Rulika Bunga Kertas dapat terus terarah dan terorganisir. Proses pemberdayaan masyarakat yang mengarah pada perubahan, setidaknya ada dua pihak yang berperan aktif didalamnya, yakni masyarakat dan pihak dari luar masyarakat yang di antaranya pemerintah desa dan perusahaan untuk mempercepat terjadinya pembaruan (Soetomo, 2013).

Setelah 2 tahun PT Pertamina Hulu Sanga Sanga mendampingi Rulika Bunga Kertas, kemandirian ekonomi masyarakat sudah mulai terlihat. Beberapa prestasi juga berhasil diraih oleh Rulika Bunga Kertas, antara lain terpilihnya Walrina Munangsir sebagai Duta Baca Kalimantan Timur Tahun 2018, Duta Pelopor Kalimantan Timur Tahun 2019, dan penghargaan Rulika Bunga Kertas Dalam Kategori Gold dalam Indonesian CSR Awards Tahun 2020. Kunjungan-kunjungan dari instansi atau pun luar daerah mulai banyak berdatangan, contohnya seperti kunjungan dari SDN 038 Samboja, SMPN 5 Samboja, SMK Utama AlJabal Nur, Dinas Pendidikan, Pemuda dan Olahraga Kabupaten Kutai Kartanegara, Dirjen Kementerian PKP2Trans, serta Kementerian Desa, Pembangunan Daerah Tertinggal dan Transmigrasi.

Kendala yang sering dihadapi dalam pengembangan Rulika Bunga Kertas adalah kurangnya pengurus yang tetap mengingat kegiatan dalam Rulika Bunga Kertas pada saat ini masih bertumpu pada prinsip keswadayaan dibandingkan keuntungan bagi individu yang terlibat di dalamnya. Rata-rata keaktifan pengurus tidak lebih dari 6 bulan. Dalam menyiasati hal ini, Walrina Munangsir terus melakukan pendekatan dengan pengurus existing dan kelompok-kelompok masyarakat khususnya para pemuda. Pemuda dinilai masih memiliki banyak waktu senggang untuk berkreativitas bersama di Rulika Bunga Kertas.

\section{Diskusi}

Rulika Bunga Kertas telah mampu membentuk kebiasaan baru yang terlembaga pada diri anak-anak dan remaja untuk melek literasi. Pada anak-anak usia dini, bacaan ringan seperti komik menjadi media efektif mereka yang gemar membaca.. Sebelum bermain, anak-anak diharuskan minimal membaca buku pengetahuan selama 15 menit setiap hari. Untuk menambah semangat anak-anak dan remaja Desa Beringin Agung, sering kali di setiap kegiatan pembelajaran diberikan perlombaan berhadiah dari para donatur.

Rulika Bunga Kertas telah bertransformasi dari yang semula hanya sebagai taman baca masyarakat, menjadi pusat pengembangan masyarakat yang kegiatannya terbagi ke dalam enam jenis literasi. Literasi yang telah dilakukan di Rulika Bunga Kertas tidak hanya sekedar literasi baca tulis, melainkan juga peningkatan ekonomi masyarakat sekitar. Salah satu contoh yakni dengan terbentuknya kelompok baru bernama Mamuja yang berada di bawah divisi literasi finansial. Mamuja menyadarkan ibu-ibu rumah tangga untuk bisa produktif dan menghasilkan peluang ekonomi baru untuk meningkatkan kesejahteraannya. Penyadaran merupakan tahapan dalam membentuk kepedulian masyarakat bahwa mereka memerlukan pengembangan kapasitas. Masyarakat kemudian sadar bahwa mereka hidup dengan berbagai potensi, namun potensi tersebut belum dimanfaatkan (Sulistyarni, 2004).

Kami mengamati apabila masyarakat hanya diberikan kewenangan dalam mengelola potensi yang mereka miliki tanpa diberi pelatihan atau peningkatan pengetahuan atau kapasitas di dalam mengelola potensi tersebut, hal itu tidak akan memberikan efek yang diharapkan ketika mengelola potensi tersebut. Hasilnya, masyarakat tetap memiliki kehidupan yang kurang sejahtera meskipun di lingkungannya memiliki potensi lokal yang besar. Selain diberikan kewenangan, PT Pertamina Hulu Sanga Sanga dengan stakeholder terkait memfasilitasi peningkatan fasilitas masyarakat di antaranya dengan pembekalan wawasan pengetahuan, kecakapan dan keterampilan ekonomi Mamuja. Pelatihan ini diperlukan untuk penyadaran pentingnya literasi dan kemampuan yang diperlukan di dalamnya untuk dikembangkan (Yusri \& Mahmud, 2020).

Pemberdayaan berarti terlibat secara kolektif baik dalam proses tahapan kegiatan sampai pada keputusan pada distribusi hasil (Suparjan \& Suyatna, 2003). Rulika Bunga 
Rachmat Dana Pratama, Abdul Raji, Hidayah Utama Lubis, Hempri Suyatna - Pemberdayaan Masyarakat melalui Program Rumah Literasi Kreatif di Kabupaten Kutai Kartanegara

Kertas telah memberikan kesempatan bagi para relawan untuk menjadi bagian dari pengurus Rulika Bunga Kertas. Masyarakat Desa Beringin Agung kemudian mengisi posisi struktural dan turut berkreasi secara aktif dan inovatif di dalamnya. Dari kegiatan ini pula, terbentuk inovasi-inovasi kewirausahaan seperti daur ulang sampah menjadi kerajinan bernilai jual, meningkatnya kemampuan menjahit Mamuja, adanya olahan makanan kemasan yang siap dijual, terbentuk kelompok seni tari, dan lain sebagainya.

Penting juga untuk digaris bawahi bahwa tanda keberdayaan salah satunya adalah kemandirian dalam mengelola potensi, sumber daya yang dimiliki, dan mengalokasikannya untuk mengatasi masalah kesejahteraan sosial (Sulistyarni, 2004). Rulika Bunga Kertas, sebagaimana hasil penelitian kami, merefleksikan argumen tersebut.

\section{Kesimpulan}

Pendidikan merupakan hak dasar bagi setiap warga negara yang pelaksanaannya diperlukan sinergitas dari berbagai pihak. Di pedesaan, keberadaan taman baca menjadi alternatif untuk mencerdaskan masyarakat. Literasi berkaitan dengan beragam kehidupan masyarakat yang terus berkembang di setiap kehidupan manusia. PT Pertamina Hulu Sanga Sanga bersama stakeholder terkait terus mendorong kemandirian Rulika Bunga Kertas agar program dapat terus berkelanjutan.

Pada tahap perencanaan, masyarakat lokal menjadi subjek utama dalam perencanaan dan pengembangan Rulika Bunga Kertas. Pengembangannya turut melibatkan lintas stakeholder baik dari masyarakat umum, pemerintah desa, maupun PT Pertamina Hulu Sanga Sanga. Pada tahap implementasi, pengembangan literasi dibagi ke dalam 6 kelompok literasi dasar dengan pendekatan pengembangan yang berbeda-beda. Pemerintah desa dan perusahaan rutin melakukan kegiatan monitoring maupun evaluasi pada Rulika Bunga Kertas untuk memastikan program dapat terus berkelanjutan.

Berdasarkan hasil analisis penelitian mengenai pemberdayaan masyarakat di Rulika Bunga Kertas, diperoleh kesimpulan bahwa keberadaan Rulika Bunga Kertas telah mampu membentuk kebiasaan baru masyarakat untuk melek literasi dengan peningkatan pengetahuan, keterampilan, dan memunculkan peluang ekonomi baru untuk masyarakat.

Sarana prasarana Rulika Bunga Kertas merupakan pendukung utama kegiatan literasi masyarakat di Desa Beringin Agung. PT Pertamina Hulu Sanga Sanga memberikan bantuan berupa perluasan Bangunan Taman Baca, peralatan, dan bahan bacaan pendukungnya. Selain dari perusahaan, banyak donatur dari pemerintah, pengusaha, dan masyarakat umum turut memberikan bantuan berupa bahan bacaan, alat peraga, dan hadiah pemantik pembelajaran di Rulika Bunga Kertas.

Untuk menunjang keberlanjutan melek literasi masyarakat di Desa Beringin Agung, Rullika Bunga Kertas turut membuat inisiatif kemandirian ekonomi di sebagian besar jenis literasi yang dikembangkan. Pada bidang literasi kebudayaan dan kewarganegaraan, upaya pemberdayaan masyarakat yang dilakukan adalah dengan pemantapan seni tari Rulika Bunga Kertas dengan menggandeng kesenian lokal dan membentuk subdivisi yang menaunginya. Pada bidang literasi sains, penerapan praktis aquaponik telah diterapkan. Pada bidang literasi digital, Rulika Bunga Kertas telah mengimplementasikan pembuatan sosial media untuk promosi lembaga, kegiatan, dan hasil produksi di dalamnya. Selain itu, pelatihan fotografi dan videografi terus digencarkan kepada generasi muda. Pada bidang literasi numerasi dan finansial, terbentuk kelompok pemberdayaan Mamuja yang rutin memproduksi produk bernilai jual. Rulika Bunga Kertas turut mempromosikan baik melalui media sosial maupun melalui para pengunjung taman baca.

Rulika Bunga Kertas telah bertransformasi menjadi pusat kegiatan masyarakat di Desa Beringin Agung yang merupakan daerah transmigrasi dan jauh dari fasilitas publik. Tidak hanya baca tulis, inisiatif tersebut pada akhirnya berkembang menjadi pusat kegiatan kreativitas masyarakat. Kini Rulika Bunga Kertas terus berkembang menjadi pusat inkubator sosial dan sekolah bakat bagi masyarakat Desa Beringin Agung. Pengunjung yang datang bahkan bukan lagi dari masyarakat sekitar saja, tetapi juga dari luar daerah.

Dalam pelaksanaan pemberdayaan masyarakat melalui kegiatan literasi pada Rulika Bunga Kertas masih ditemukan kelemahan dalam pelaksanaannya. Saran untuk pengembangan Rulika Bunga Kertas yakni perlu 
adanya penambahan pengurus. Dalam penelitian dapat terlihat bahwa Walrina Munangsir adalah local heroes yang paling banyak berperan dalam membesarkan Rulika Bunga Kertas. Dengan semakin berkembangnya Rulika Bunga Kertas, tentu beban Walrina Munangsir akan semakin berat sehingga pengurus yang baru semestinya dapat meringankan beban dan menambah layanan maupun keterampilan kepada masyarakat yang lebih variatif dan inovatif.

\section{Referensi}

Alwasilah, A.C. (2002). Pokoknya Kualitatif: Dasar-Dasar Merancang dan Melakukan Penelitian Kualitatif. Bandung: Dunia Pustaka Jaya.

Central Connecticut State University(2016, 07 March). World's Most Literate Nations Ranked.https://www.ccsu.edu/wmln/rank. html accessed on 6 April 2021.

Clay, M. M. (2001). Change Over Time in Children's Literacy Development. Portsmouth: Heinemann.

Dwiyantoro. (2019). Peran Taman Bacaan Masyarakat Mata Aksara dalam Menumbuhkan Minat Baca Pada Masyarakat. Jurnal Kajian Informasi \& Perpustakaan, 7(1), pp. 19-32.

Fadila, A. (2020). Taman Baca Tanah Ombak Dalam Meningkatkan Literasi Baca Anak Di Pantai Purus. Journal of Information and Library Studies. 3(1), pp. 55-74.

Gong, G. A., \& Irkham, A. I. (2012). Gempa Literasi: dari Kampung untuk Nusantara. Jakarta: Kepustakaan Populer Gramedia.

Herdiansyah, Haris. 2010. Metode Penelitian Kualitatif untuk Ilmu-ilmu Sosial. Jakarta : Salemba Humanika.

Holik, A. (2013). Peran Taman Bacaan Masyarakat (TBM) Sudut Baca Soreang dalam Meningkatkan Minat Baca Masyarakat di Kabupaten Bandung. Jurnal Pengabdian Kepada Masyarakat, 3(1), pp. 50-56. doi: http://dx.doi.org/10.30999/jpkm.v3i1.41.

Kementerian Pendidikan dan Kebudayaan. (2017, 17 April). NSPK (Norma, Standar, Prosedur, Dan Kriteria) Petunjuk Teknis Pengajuan, Penyaluran dan Pengelolaan Bantuan Taman Bacaan Masyarakat Rintisan. Jakarta: Kementerian Pendidikan dan Kebudayaan. http://repositori. kemdikbud. go.id/1233/ accesed on 8 April 2021.
Kern, R. (2000). Literacy and Language Teaching. Oxford: Oxford University Press.

Otoritas Jasa Keuangan. (2017). Strategi Nasional Keuangan Nasional Indonesia (Revisit 2017). Jakarta. https://www.ojk.go.id/id/beritadan-kegiatan/publikasi/Documents / Pages/Strategi-Nasional-Literasi-KeuanganIndonesia-(Revisit-2017)-/SNLKI\%20 (Revisit\%202017)-new.pdf accessed on 7 April 2021.

Perpustakaan Nasional Republik Indonesia. (2007). Undang-Undang Republik Indonesia Nomor 43 Tahun 2007 tentang Perpustakaan. Jakarta. https://www.perpusnas. go.id/law-detail.php?lang=id\&id= 170920114322Ir9g6HhRuc accessed on 7 April 2021.

Perpustakaan Nasional Republik Indonesia. (2020). Peraturan Perpustakaan Nasional Nomor 7 Tahun 2020 Tentang Rencana Strategis Perpustakaan Nasional Tahun 2020-2024. https://jdih.perpusnas.go.id/ detail/305 accessed on 7 April 2021.

Pramudyo, G. N., Ilmawan, M. R., Azizah, B., Anisah, M., \& Deo, Y. (2018). Inovasi Kegiatan Taman Bacaan Masyarakat (TBM). Lentera Pustaka: Jurnal Kajian Ilmu Perpustakaan, Informasi dan Kearsipan, 4(1), pp. 29-38. doi: https://doi.org/10.14710/lenpust. v4i1.17332.

Saepudin, E., Sukaesih, S., Rusmana, A. (2017). Peran Taman Bacaan Masyarakat(TBM) Bagi Anak-Anak Usia Dini.Jurnal Kajian Informasi \& Perpustakaan, 5(1), pp.1-12

Soetomo. 2009. Pembangunan Masyarakat "Merangkai Sebuah Kerangka". Yogyakarta: Pustaka Pelajar.

. (2011). Pemberdayaan Masyarakat: Mungkinkah Muncul Antitesisnya?. Yogyakarta: Pustaka Pelajar. - (2013). Masalah Sosial dan Upaya Pemecahannya. Yogyakarta: Pustaka Pelajar.

Sudiana, N. (2020). Upaya Meningkatkan Minat Baca Siswa Kelas VII SMP Negeri 2 Sukasada Tahun Pelajaran 2017/2018 Melalui Gerakan Literasi Sekolah dengan Pocari dan Puding. Journal of Education Action Research, 4(1), pp. 10-16.

Sunaryo, Bambang. (2013). Kebijakan Pembangunan Destinasi Pariwisata Konsep dan Aplikasinya di Indonesia. Yogyakarta: Gava Media. 
Rachmat Dana Pratama, Abdul Raji, Hidayah Utama Lubis, Hempri Suyatna - Pemberdayaan Masyarakat melalui Program Rumah Literasi Kreatif di Kabupaten Kutai Kartanegara

Suparjan \& Suyatna, H. (2003). Pengembangan Masyarakat dari Pembangunan Sampai Pemberdayaan. Yogyakarta: Aditya Media.

Suragangga, N. M. I. (2017). Mendidik Lewat Literasi Untuk Pendidikan Berkualitas. Lembaga Penjamin Mutu Institut Hindu Dharma Negeri Denpasar. Jurnal Penjaminan Mutu, 3(2), pp. 154-163. doi: http:// dx.doi.org/10.25078/jpm.v3i2.195.

Wandasari, Y. (2017). Implementasi Gerakan Literasi Sekolah (GLS) Sebagai Pembentuk Pendidikan Berkarakter.Jurnal Manajemen, Kepemimpinan Dan Supervisi Pendidikan,
1(1), pp. 325-342. doi: http://dx.doi. org/10.31851/jmksp. v2i2.1480.

Winarni, T. (1998). Memahami Pemberdayaan Masyarakat Desa Partisipatif dalam Orientasi Pembangunan MasyarakatDesa Menyongsong Abad 21: Menuju Pemberdayaan Pelayanan Masyarakat. Yogyakarta: Aditya Media.

Yusri, A., \& Mahmud, A. (2020). PKM Pembuatan Taman Baca Berbasis Budaya Lokal untuk Meningkatkan Kesadaran Literasi Sejak Dini. MATAPPA: Jurnal Pengabdian Kepada Masyarakat, 3(2), pp. 164-169. doi: http:// dx.doi.org/10.311 00/matappa.v3i2.83. 